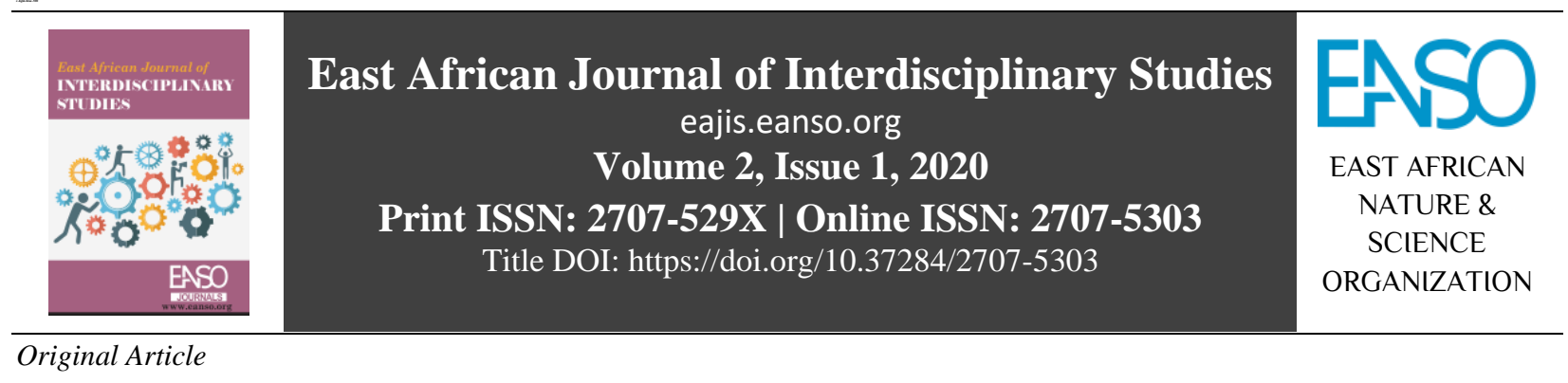

\title{
Nollywood, Religion and Development in Nigeria
}

\author{
Dr. Prisca A. Gobo ${ }^{1 *}$ \\ ${ }^{1}$ Department of History and Diplomatic Studies, University of Port Harcourt, Nigeria. \\ * Author for Correspondence Email: drpriscaabiye1@gmail.com
}

Article DOI: https://doi.org/10.37284/eajis.2.1.177

\section{Date Published: ABSTRACT}

30 June 2020 The Nigerian film industry, popularly called Nollywood has been a source of pride since it officially took off in 1992 with the production of the first direct-

Keywords: to-video film, Living in Bondage. Religion, on the other hand, has become a topic of growing interest among scholars worldwide. However, in Nigeria,

Nollywood, while Nollywood is peddling exaggerated stereotypes and one-sided accounts Film Industry, of its traditional religion and culture, thereby promoting the get rich quick life, Religion, many religious leaders intensify that same way of life by making the members Nigeria. believe that one can go to bed a pauper and wake up wealthy just by praying and sowing seeds. This article sought to interrogate the effects and consequences of Nollywood and Religion on Nigerian development. This article examined the neo-colonial mindset that makes Nollywood writers, producers and religious leaders magnify the ills in our society while glorifying the western life. Indeed, religion and Nollywood with the many followers, listeners and viewers can influence Nigeria and the diaspora positively in more ways than one. Through the multidisciplinary approach to historical interpretation, this article identified ways to regulate and promote development in Nigeria through religion and Nollywood.

\section{APA CITATION}

Gobo, P. (2020). Nollywood, Religion and Development in Nigeria. East African Journal of Interdisciplinary Studies, 2(1), 4962. https://doi.org/10.37284/eajis.2.1.177

\section{CHICAGO CITATION}

Gobo, Prisca. 2020. "Nollywood, Religion and Development in Nigeria". East African Journal of Interdisciplinary Studies 2 (1), 49-62. https://doi.org/10.37284/eajis.2.1.177.

\section{HARVARD CITATION}

Gobo, P. (2020) "Nollywood, Religion and Development in Nigeria", East African Journal of Interdisciplinary Studies, 2(1), pp. 49-62. doi: 10.37284/eajis.2.1.177.

\section{IEEE CITATION}

P. Gobo, "Nollywood, Religion and Development in Nigeria", EAJIS, vol. 2, no. 1, pp. 49-62, Jun 2020. 


\section{MLA CITATION}

Gobo, Prisca. "Nollywood, Religion and Development in Nigeria”. East African Journal of Interdisciplinary Studies, Vol. 2, no. 1, Jun 2020, pp. 49-62, doi:10.37284/eajis.2.1.177.

\section{INTRODUCTION}

The Nigerian movie industry popularly known as Nollywood has gained international acceptance and recognition since its inception in 1992. Nollywood has contributed hugely to the growth and development of the nation. However, consciously or unconsciously, Nollywood is peddling negative stereotypes of our religion and culture. On the other hand, Nigeria has witnessed a dramatic upsurge of religious intolerance and misinterpretation just like other parts of the world. In other words, both Nollywood and religion are taking Nigeria on a downward spiral with all its attendant negative consequences. By contextualizing the historical significance of Nollywood and religion, this article demonstrates that they could be intentionally positioned to birth growth and development considering their large followership, viewership and practitioners.

Leaning on historical precedence, this article seeks to explore the pitfalls and dangers associated with the misrepresentations peddled by Nollywood and our religious institutions. By situating these issues in a larger historical context, the article argues that it is imperative to review, reassess and reposition Nollywood and religion to produce the muchneeded development especially in a fast-changing world occasioned by globalization. Why this topic? The reason is simple: Nollywood and religion both have large viewership and followership; they, therefore, wield tremendous influence on the populace. Nigeria as a nation can leverage on this as its effective utilization would yield great dividends for sustainable national development.

\section{DEFINITION OF CONCEPTS}

The concepts to be defined are Nollywood, Religion and Development.

Nollywood is the Nigerian film Industry which officially gained recognition in 1992 with the production of the film titled Living in Bondage. Since its inception, it has provided wealth and fame to Nigeria and the practitioners. It has also faced many challenges and criticisms.
Religion: There is no scholarly consensus on the definition of religion because religion means different things to different people through time and space. However, a few of the definitions by different scholars will be considered for this article. Gawmna defines religion as man's attempt to relate with supernatural forces as part of man's search for meaning, understanding and explanation of life (Quadri, 2016, p. 10). Brein maintained that religion is the whole complex of attitudes, convictions, emotions, gestures, rituals, beliefs and institutions by which we come to terms with God and express our fundamental relationship with reality or God (Quadri, 2016, p. 40). On the other hand, An-na'im looks at religion as that which entrenches its exclusivity and therefore defines religion (a) as a system of beliefs (b) practices (c) institutions and relationships that are used by a community of believers to identify and distinguish itself from other communities (Quadri, 2016, p. 50).

Development: The Cambridge English dictionary defines development as the process in which someone or something grows or changes and becomes more advanced. The development could also be defined as a process that creates growth, progress, positive change or the addition of physical, economic, environmental, social and demographic components. Furthermore, the World Commission on Environment and Development (Brundtland Commission) defines sustainable development as the "development that meets the needs of the present without compromising the ability of future generations to meet their own needs." Having given the definitions of the keywords, the next step would be an in-depth analysis of the concepts.

\section{RELIGION IN NIGERIA AND THE COLONIAL LEGACY}

Religion is an important factor in the lives of human beings all over the world. In Africa, religion is life itself and no one thinks of life without simultaneously thinking of religion. Because of the centrality of religion in the African consciousness, social developments have always assumed a 
religious character (Kilani cited in Ugiomoh et al., 2017). Religion is an invisible thread that runs through the very fabric of African society. Owing to the fact that Africans are deeply religious people, it informs my decision to analyse the religious aspect of this discourse before assessing Nollywood because the Nollywood industry is affected by the religious impulses of Africa.

\section{African Traditional Religion}

In Nigeria, three main religions are recognized: The African Traditional Religion (ATR), Christianity and Islam. ATRs are timeless, beginning with the origin of human civilization on the African continent perhaps as early as 200,000 BCE when the species, Homo sapiens is believed to have emerged (Belz, 2012). Africa, the place of origin of all humans, had various indigenous spiritual systems, usually called ATRs. This was based on the fact that the Africans believed in a Supreme Being who is the creator of the universe. Though various names are given to God in different regions of Africa, the reality which the names express is the same.

African Traditional Religion (ATR) refers to the indigenous or autochthonous religions of the African people. It deals with their cosmology, ritual practices, symbols, arts, society and so on (Olupona, 2014). In the African context, religion is a way of life, therefore it relates to culture and society as they affect the worldview of Africans. Narratives about the creation of the universe (cosmogony) and the nature and structure of the world (cosmology) form the core philosophy of African religions. The narratives are conveyed in a linguistic form that scholars often refer to as myth. The term "Myth" in African religions refers to sacred stories that are believed to be true by the practitioners. The myths reveal significant events and episodes of the most profound and transcendent meaning (Mbiti, 1969). Myths are not fixed but they retain similar structures and purposes which are to describe the way things were at the beginning of time and to explain the cosmic order. They generally involve superhuman entities, gods, demigods, spirits and ancestors.

The fact that myths have endured for generations gives them their authority and authenticity. Every generation reinterprets the myths to suit its needs and time. The myths provided the African society with unwritten guidelines for establishing institutions of morality, ethics and conduct to foster peace and progress. ATR serves as the structure, around which all other activities such as cultural, economic, political and social organizations are built (Gbenda cited in Mangut \& Wuam 2012). Every ethnic group in Africa has developed a complex and distinct set of religious beliefs and practices for centuries which have defied the assault from European and Arabic cultures. Despite their seemingly unrelated aspects, there are common features to these systems practised by the various ethnic groups suggesting that African traditional faiths form a cohesive religious tradition. Evidence such as archaeological discoveries, carbon dating and DNA have corroborated certain elements contained in the African Myths, legends and narratives. These modern forms of dating and verifying information and evidence have confirmed that African oral culture and religion are as authentic as those communicated through writing.

\section{Christianity and Islam}

The spread of Christianity and Islam has affected the practice of African Traditional religion adversely. Christianity was the first world religion to appear on the African continent in about the first century across North Africa. It was later overtaken by Islam in the $7^{\text {th }}$ century by military aggression, commercial activities and missionary efforts of Persian and Arab merchants who introduced Islam in East Africa. In the $15^{\text {th }}$ century, Christian missionaries became the first group of Europeans to invade and occupy West Africa. Western colonizers negotiated and drafted treaties with African leaders, stripping Africans of their Lands, depopulating the countryside, destabilizing their economics, overturning the political rule, and uprooting cultural and lineage continuity. By the 1700s, Islam had become widespread in West Africa and by the 1900s, Christianity was firmly established in most African countries including Nigeria.

Islam is firmly entrenched in Northern Nigeria while Christianity is mostly practised by Southern Nigerians. The "demonization" of Traditional African Religion was a well thought out plan of the Arab and Christian missionaries. They linked the 
ATRs with the devil and evil. By so doing, they hoped to uproot their cultures, traditions, languages, identity and introduce a foreign culture. Because the African culture and traditions have always been linked with religion, this had devastating effects on the African continent, people and religion. The colonizers and missionaries demonized ATRs deliberately to make Africans feel inferior and see Europeans as superior to make Africans amendable to exploitation. Paradoxically, the Africans came to believe such stereotypes and began to despise their traditions. Only now are we starting to question this negative colonial legacy?

Despite a large number of converts to Christianity and Islam, traditional religions of Africa still have a stronghold on Nigerians especially in times of crisis or personal tragedy. The three religions have large followership and enjoy the freedom of religious expression. The Nigerian constitution has attempted to maintain unity through religion. Thus section 10 of the 1999 constitution states "the government of the federation or a state shall not adopt any religion as a state religion."

Section 38 of the same constitution declares that "Every person shall be entitled to the freedom to change his religion... to manifest and propagate his religion or belief in worship, teaching, practice and observance" (Ojoajogwu, 2014).

Christianity and Islam are now officially recognized and patronized alongside ATR in Nigeria. Nigerians now take pride in putting on their best dresses on Fridays and Sundays to go to Churches and Mosques respectively to worship. But there is more to religious practice in Nigeria than meets the eye. In the last few decades, Nigeria has witnessed a dramatic upsurge of religious fundamentalism and intolerance. Many are leaving the Orthodox Churches and rushing to the Pentecostal Churches in their millions. And on the other hand, religious fanatics are destroying religion, bombing churches and mosques, and killing, maiming and displacing many, to these we will turn.

\section{RELIGIOUS INTOLERANCE AND MISREPRESENTATION}

How do we have any meaningful development in a country where religion is used, misused and abused by all and sundry? Of what value, importance and relevance is a religion to economic development in a country still engrossed in the spate of senseless killings and maiming of innocent lives orchestrated by Boko Haram Insurgency? Or indeed, how is national development possible in a country where the leaders and practitioners of the three recognized religions are engrossed in manipulating religion for their aggrandizement?

Christianity and Islam in Nigeria are often antagonists, leading to ethnic and religious conflicts which result in loss of lives and destruction of properties. In February 1986, Palm Sunday procession became a disaster in Ilorin, the Kwara State of Nigeria as Christians clashed with Muslims destroying three Churches in the process (Falola, 1998). Furthermore, from 1980-2011, more than 11,000 Nigerians died and properties worth millions of dollars were destroyed in riots between Muslims and Christians (Adebayo, 2012).

The Boko Haram sect has strengthened its hold over the region of Maiduguri in Borno State, as well as expanded its operating area to include the major Muslim population centres of Northern Nigeria (Cook, 2012). They have moved from high profile operations with international implications like the suicide attack on the United Nations headquarters in Abuja on August 26, 2011, to an escalation of attacks on Nigerian Christians as well as a renewed focus on attacks against the Nigerian military. Many armies and police officers have been killed by Boko Haram (Cook, 2012).

Book Haram's goal of creating a Sharia State has remained constant and they have expanded their attacks to Jos and Abuja both of which have a reasonable expatriate and Christian population. These operations used suicide attacks against Churches and killed at least 25 people. There have also been major attacks on Christian targets on February 5th, 6th, 10th, 11th, and 24th, all in Maiduguri, Adamawa and Jos in 2016. There were more attacks on February 19th, in Suleja near Abuja and February 2, 2012, in Abuja and Jos. The attack 
in Jos was a suicide bombing (Belz, 2012). There were attacks against the Armed Forces General Headquarters in Kaduna on February 9, 2012, attacks against schools, markets, hospitals and public places in different parts of Nigeria. It's even worse today as Churches, Mosques and other public places are bombed regularly. At least 275 girls were taken from Government Secondary School in Chibok town by Boko Haram in 2014 (Haruna, 2019). Five years later, 112 of the girls are still missing. Amnesty International reported that 60 people were killed in an attack on February 1, 2019, by Boko Haram in Rann town in Borno State (Haruna, 2019).

Fears of the renewed attack caused the exodus of more than 30,000 people from the town of Rann in the Borno State of Nigeria. These are just a few of the many cases of violence and destruction of lives and properties by religious extremists. While Boko Haram is causing mayhem on the Nigerian populace and economy, the Pentecostal Church has become a movement that is sweeping across the nation converting both Christians and Muslims. Yet, the secret of the success of the Pentecostal leaders and Pastors is simple. They simply studied the Nigerians (Kyeyune, 2012):

i. The average Nigerian has a strong belief in destiny. They believe that no matter how hard you work or how lazy you are, the will of the gods will prevail.

ii. They do not take responsibility for anything even when they act foolishly, something or someone else is responsible.

iii. They believe that the gods must be appeased at all times for anything good to happen in their life.

In the past, the appeasement was done at the family or communal deities. Such rituals are now outdated due to the colonial legacy and so the Pentecostal Churches are now receiving the sacrifices. The Pastor or prophet in designer silk suit from Milan has taken over from the village diviner of the ATR and rituals are no longer performed with goats and cockerels but with tithes and American dollar offerings (Kyeyune, 2012). They believe that they can live in sin and grace will continue to abound as long as they keep paying their tithes and offerings and sowing seeds, they will get away with any sin. Holiness is not necessary, deliberate planning and execution of set goals are not necessary. All you need do is appease the pastors and prophets and your success is guaranteed, so they think.

This scenario explains why Churches and Mosques are increasing and yet sin is multiplying and the crime rate is skyrocketing every day. And Nollywood also reflects this abuse and misinterpretation of religion faithfully.

Against this background, Nollywood was born. The Nollywood Industry was born into a Nigerian society that had been bastardized by colonialism. A colonial experience which programmed and shaped the African to loathe everything African, and glorify everything foreign. A colonial experience which relegated Africa to the background mentally, spiritually, psychologically, socially, culturally, religiously, and otherwise, only now are we beginning to question this colonial legacy.

\section{NOLLYWOOD - A BRIEF HISTORY}

The Nigerian Movie Industry popularly known as Nollywood gained recognition with the first movie titled "Living in Bondage", produced by Kenneth Nnebue in 1992. It was the first commercially viable film produced in Nigeria. However, the history and development of the Nigerian motion picture date back to the colonial era. Film as a medium was introduced to Nigeria in the late $19^{\text {th }}$ century as peephole viewing of motion picture devices. They were replaced with better motion picture exhibition devices in the early $20^{\text {th }}$ century. The cinema business grew quickly after Nigeria gained independence in 1960 and more cinema houses were opened in Lagos and other parts of the country. This allowed theatre practitioners like Hubert Ogunde and Moses Olaiya to make the transition to the big screens.

Colonial filmmakers started making films for Nigerian audiences from the 1920s using the mobile cinema as a means of exhibition. However, Nigerian content in the films was non-existent. They were solely produced and distributed by foreigners.

Wale Adenuga's Production "Papa Ajasco" became the first blockbuster after this policy, grossing 
approximately N21, 555, 673 in three days in 1984. In 1985, Moses Olaiya also grossed N44, 180, 499 in five days. More people like Wole Soyinka, Duro Ladipo and Ken Saro Wiwa came into the scene.

In 1972, the head of state, Yakubu Gowon established the Indigenization Decree to stop the influx of foreign culture to Nigeria through films and ensured the transfer of ownership of about 300 film theatres in the country from the foreigners to Nigerians. More Nigerians became involved in the cinema and film business as a result of this policy. Though most Nigerians were addicted to Foreign Television Soaps like Another Life, Dynasty, Dallas, The Cosby Show and others. By the mid1980s, Nigerian soaps had started to grace the screens of National Television Network. According to Shaka (2003):

The experiment began with the highly-rated Lola Fani-Kayode's mirror in the Sun (1985), followed by Victims (1988), created by Mabel Oboh, Ripples (1988) created and directed by Zeb Ejiro, Behind the Clouds created and directed by Matt Dadzie; Supple Blues(1988) created by Paul Emeni and directed by John Ndanuse; and Checkmate(1991) created by Amaka Igwe and directed by Bolaji Dawodu (p. $55)$.

The Structural Adjustment Programme (SAP) and the unpatriotic action of the multinational companies in Nigeria like Lever Brothers, UAC, and AG Leventis who began to sponsor Mexican soaps among other things squeezed indigenous filmmakers out of business (Haynes, 1995; Haynes \& Okome, 1998; 26, Shaka; 2003).

As the film business was being forced out of the market by SAP, the resilient spirit of the Nigerian was showcased through the production of the first film shot on the video format rather than on the celluloid format for commercial consumption. The first film to be produced was Living in Bondage by Kenneth Nnebue signalling the birth of Nollywood. Suffice it to say that the release of the blockbuster confirmed the commercial viability of what has grown to become a multibillion Naira entertainment industry that has produced many movies and movie stars (Shaka cited in Ugiomoh et al, 2017).
Today, the Nollywood industry is undoubtedly one of the largest employers In Nigeria and is rated by UNESCO as the second-largest film industry in the world (Husseini \& Sunday, 2019). Sadly, many Nollywood writers and producers have adopted the neo-colonial mindset in their productions which focus on bastardizing Nigerian religion and culture. Ironically, from the very first Nollywood production, Living in Bondage, producers have tended to cast the Nigerian traditional life as evil, as well as portraying Nigerians as people who make their money through the occult, voodoo and human sacrifice.

Nollywood films have large viewership because one can easily relate to the stories told and the moral implications. And you do not need a fertile imagination to understand the plots or find it difficult to connect to the spiritual impulses of the characters. Nollywood truly reflects the innate character of the Nigerian. However, the negative portrayal of our society through Nollywood films is causing society more harm than good. Anytime Nollywood films focus on a Nigerian village or city, there are some constant narratives:

i. The village is the home of poverty, while the city is the place of wealth and influence.

ii. The village is the home of witches and wizards while the city is the home of good men and women.

iii. The traditional religion in the villages is evil but the Christian religion in the city is the good that overcomes the darkness in the village.

iv. The village is a lawless society where one man can seize the property of anybody, especially the widows with impunity unless he is stopped by divine intervention, while the city is the land of order.

v. Whenever traditional practices are shown in Nigerian films, they are shown to be evil. In the end, a pastor will be invited to destroy the "forces of darkness" (Onwuka, 2017).

Owing to the negative scenario painted by Nollywood films above, the youths do not want to live in the village because they believe that they can only become successful in the city. Incidentally, 
there are many wealthy people in the village and many poor people in the cities and we know many of them. There are evil people in the city and the villages just like there are laws in the village and the city depending on how they are enforced.

One is forced to ask in which fairy Nigerian village did these evil things take place. We are not disputing the fact that there are evil occurrences in Nigerian society, but must they exaggerate the ills in the Nigerian society and glorify the foreign culture just to sell movies? By so doing they have inadvertently made the world to question the source of wealth of every wealthy Nigerian. Meanwhile, many poor people believe these stories and they are desperate to get rich too so they kidnap, kill, and do all manner of things to make money.

Films are sources of advertisement for countries around the globe. Nollywood producers and practitioners always claim that they are telling their own story which is not far from the truth, but they need to find ways of telling their stories without demonizing our traditional ways of doing things. This should be seen as a national clarion call to all stakeholders. Americans always portray their country as God's own country where everything is perfect and efficient but we know that is not true. Hollywood movies even when shot in other locations in the world always make the American and America look good. The same with Indian (Bollywood) movies, Chinese movies and others, which always proudly showcase their culture positively. Nollywood needs to stop causing so much damage to the Nigerian tradition and society. They have killed our culture, destabilized family cohesion and demonized rural communities. What happened to our selfless community life in the villages and traditional conflict resolution techniques which they should be promoting instead of these one-sided negative narratives?

This negative image of the Nigerian society showcased by Nollywood is not only affecting Nigeria but the whole of Africa has a bad image in the world. BBC, CNN, Sky News, France 24 and others have enough negative news to report about us (Onwuka, 2017). Why does Nollywood feel the need to contribute to the negative narrative through its films which are watched all over the world?
Nollywood has the power to change and control the narrative and positively tell the African story for posterity because of the millions of viewers, followers and admirers who could become our ambassadors tomorrow. Sacrificing our whole essence on the altar of personal wealth and fame is not worth it in the long run. That would be tantamount to mortgaging the future of the Nigerian society.

It is bad enough that Nollywood films relegate the African culture and religion to the background, but it also prides itself on promoting the foreign culture at the expense of their own. While Hollywood and Bollywood are busy promoting their society through their films, Nollywood is not just destroying her own culture but promoting foreign cultures as well. This is bad for the Nigerian society and the African continent at large and it is bound to have a devastating effect on the development of the society in more ways than one.

\section{NOLLYWOOD AND NIGERIAN DEVELOPMENT}

The Nigerian film industry popularly known as Nollywood is globally recognized as the second largest film producer in the world, second only to Hollywood. It is one of the priority sectors identified in the Economic Recovery and Growth Plan of the Federal Government of Nigeria. The industry currently accounts for 853.9 billion Naira equivalent of 7.2 billion dollars or 1.42 percent of Nigeria's GDP (Omanufeme, 2016). Based on the huge quantity and quality of films produced, economic observers consider Nollywood one of the major planks on which to diversify the Nigerian economy (Omanufeme, 2016). According to the Film Makers Association of Nigeria, every film in Nigeria had a potential audience of 15 million people in Nigeria and about 5 million outside Nigeria.

Nollywood added two million jobs to the Nigerian economy in twenty years. This is clear proof that it is one of the most profitable and most recognized contributors to Nigerian economic development (Sahara Reporters, 2014). The President of the Association of Movie Producers in Nigeria (AMP) in 2014, Zik Zulu said that the Industry has 
contributed much to the growth of the nation's economy. He further stated that:

the upsurge in employment in the billion-dollar industry has had a substantive impact on the nation's economy and its growth. Today you have an industry that is worth over two billion dollars, employing over two million Nigerian Youths, helping in a way to check the restive situation in the country (Sahara Reporters, 2014).

The cost of producing a movie in Nigeria is between 25,000 to 70,000 dollars on average. Films are produced within a month and are profitable within two to three weeks of release. The Nigerian movies' popularity has been attributed to their low unit cost and their "indigenous content of issues relevant to a mass audience" (Moudio, 2013). Through a combination of African storylines which are relatable and western technology, "these films document and recreate socio-political and cultural events." The former director-general of the United Nations Educational, Scientific and Cultural Organization, Koichiro Matsuura, said that:

film and video production are shining examples of how cultural industries, as vehicles of identity, values and meanings, can open the door to dialogue and understanding between peoples, and also to economic growth and development, and this has been demonstrated by Nollywood albeit fraught with difficulties (Moudio, 2013).

The industry has been adjudged to be successful in Africa partly due to its acceptance and recognition. They have been able to tell their own story in their African way and African's can identify and relate to it.

\section{GROWTH AND EXPANSION OF NOLLYWOOD}

The movies are significantly influencing cultures and the film actors are becoming household names across the globe. The movies are influencing cultures in more ways than one, from dressing to speech and Nigerian slangs. This is attributed to the fact that Nigerian films told "relatable" stories.
The industry has grown and expanded in terms of quality and quantity over time. Nollywood now has movies in Nigerian languages that are translated into the English language. They have movies in the languages of the three major ethnic groups in Nigeria which are Hausa, Yoruba and Ibo, the more reason to transmit the positive, productive and progressive aspects of their African story (Schnell, 2017). The thirst and hunger for local productions have made way for the rise of pay-per-view television on the continent which in turn has helped put some funding in the hands of producers, either by purchasing their content or commissioning productions. The rise of internet use on the continent has helped bridge a little of the distribution problems as the content is also now available online.

The use of smartphones is also contributing to a production boom. More platforms are created daily to meet up with the increasing demand of the Nollywood industry. Platforms such as Ebony Life Television owned by Mo Abudu and Iroko Television created by Jason Njoku offer new distribution channels for the more than 2,000 Nollywood films produced annually (Schnell, 2017). This implies more employment and wealth for the people. An increase in demand for programming is likely to generate new opportunities for content producers too. The technology company pays filmmakers about 10,000 to 25,000 dollars for the right to stream their content for a period of time and claims to be the world's largest online distributor of African content, with a catalogue of 5,000 Nollywood films (Schnell, 2017).

As the industry grows, consumer's expectations are changing with the times and current practices, pricing and delivery methods would need to be reviewed. With the emergence of alternative movie distribution technologies such as those offered by services such as Apple store and Netflix, consumers will demand more. The need for home content is crucial to the development of the industry and by extension the nation (Schnell, 2017). Content is quickly going digital with an explosion of film content in all forms. Creating the capacity to make qualitative content is imperative if the industry must move forward. 
The first Nollywood film on Netflix is "Lion Heart", produced by Genevieve Nnaji followed by the "Wedding Party" signifying that Nollywood has indeed gone global (Schnell, 2017). The Nollywood film "Wedding Party" premiered at the Toronto International Film Festival in Canada and it became the first Nollywood film to come close to grossing half a billion naira (1.6 million dollars) in box office sales within two months of its release, shattering previous records (Odion, 2018). Many more good films have been produced and patronized internationally with an international cast such as "A Trip to Jamaica" produced by the international Comedian and actor Ayo Makun popularly known as AY featuring Vivica A. Fox and other Hollywood actors and "Dr. Bello" (the first Nollywood movie to debut in United State movie theatres), featuring Isaiah Washington, just to name a few.

The 2014 report from the United States International Trade Commission (USITC), reports that Nollywood generates, on average, 600 million dollars a year for the Nigerian economy (Oh, 2014). This report also estimates that it employs more than one million people (excluding pirates), making it Nigeria's largest employer of labour after agriculture.

Nigeria is in search of an economy that is non-oil dependent and Nollywood seems to be a viable option considering the huge success it has recorded despite the lack of financial support from the government until very recently. The industry is a significant part of the Arts, Entertainment and Recreation sector which contributed 2.3\% (239 billion nairas) to Nigeria's GDP in 2016 (PwC, 2017). Nollywood is one of the priority sectors identified in the Economic Recovery and Growth Plan of the Federal Government of Nigeria with the hope that it will enjoy more support from the government.

Most of the actors are household names and familiar faces not only in Nigeria but across the world. Some of these actors are Genevieve Nnaji, Omotola Ajalade Ekeinde, Richard Mofe Damijo, Ramsey Nouah, Sam Dede, Pete Edochie, Stephanie Okereke, Liz Benson, Olu Jacobs, Jim Iyke and others too numerous to mention. Many of them are international award-winning actors in addition to national awards. Most of them have diversified and delved into movie production, directing, singing, reality shows, talk show hosting; talk shows, politics, screenwriters, Entrepreneurs, and so on, but Nollywood gave them the platform. Some of them are even cultural and global ambassadors of international organizations. These include Joke Silva who is the United Nations Goodwill Ambassador for human trafficking; Omotola Ajalade - Ekeinde, who is United Nations World Food Programme ambassador and an Amnesty International activist, Stephanie Linus was named UNFPA Regional Goodwill Ambassador for West and Central Africa on March 8, 2017, among others. These are developmental strides worthy of emulation by the youths.

Some of them are brand ambassadors of various telecommunication companies such as MTN, GLO, and 9 mobile. These are living proofs of Nollywood dynamism. Nonetheless, existing challenges will have to be addressed to take Nollywood even further on the path of growth and development of the nation. The industry is in dire need of funding and concerted effort to reduce piracy through better enforcement of the copyright laws (which already exist) and punishment of offenders are some of the issues to be addressed. But most importantly, the issue of misrepresenting, misinterpreting, demonizing and bastardizing the African religion and culture through Nollywood productions must stop.

\section{CONTENT AND QUALITY OF NOLLYWOOD PRODUCTIONS}

There must be a conscious effort to intentionally stop telling a one-sided account of the African story which is negative. Nollywood needs to present a balanced view of African life before and after the advent of the European colonialists, thereby puncturing the negative narrative of Africa by foreigners.

The idea is not to glorify Africa but to present a society that was not and is not irrational or lawless, even though it has its flaws. The earliest written records of Africa are found in the reports of European travellers, explorers, missionaries and colonial agents which came in contact with the Africans in the fifteenth century. Their writings 
were not scholarly or systematic studies but casual observations and superficial accounts designed to appeal to western mentality and prejudice (Mangut \& Wuam, 2012).

These accounts revealed their cultural and racial bias and prejudice which served their ultimate goal of exploitation of the African people. Unfortunately, and paradoxically, the Africans also came to believe these fallacies and Nollywood films are merely a reflection of the mental slavery of Africans caused by this colonial mentality.

Africans forget that to be effective, the development process must begin by transforming the economy from its colonial, externally responsive structure to one which is internally responsive (Rodney, 1983). Sadly, Africans have followed their colonial exploiters over the years blindly even when their own experiences continue to defy it. Our greatest need is a process of mental decolonization and Nollywood being the mirror of the Nigerian society needs to champion this cause. African popular culture is rooted in the belief systems, socio-cultural practices and moral values of the masses and Nollywood must take cognizance of this fact in their productions.

There is a need to study the popular culture of Africa because of the "vital roles they play in the social, psychological, physical and spiritual wellbeing of the African peoples". Bame analyses four African traditional popular cultural genres: traditional dance, drama, festivals and funerals (Bame, 1991). In other words, traditional entertainment had themes centred on the virtues and importance of their ethnic groups, the beauties of their land, their urban situation, satirizing some customs and practices or behaviours they find obnoxious. Such examples include the Izibongo Workers Poetry of Durban, South Africa which helped their struggle against apartheid, the ebyevigo of the Urhobo of southern Nigeria and the kalela dance of the Bisa people of the Copper belt region of Zambia. These are a few of the worthy examples of African entertainment that played important roles in the social life of its performers, before Nollywood. They provided recreation and revitalization and a source of ethnic solidarity for the people.
The fact that traditional African belief-systems which provided a fertile ground for the growth and development of popular culture and by extension the nation were thoroughly denigrated by the British colonizers and their missionary allies made their converts to see popular traditional entertainment as forms of idol worship. Unfortunately, Nollywood is doing the same.

Nollywood producers need to do extensive consultations with historians, archaeologists, and religious experts in African history before producing their movies, especially their historical movies. The much acclaimed and published Nollywood film "Invasion 1897" is a historical movie that left much to be desired. I was embarrassed when I watched the film and noticed that the much talked about power of the Legendary Benin King and Kingdom was not demonstrated but only talked about. Too many words were spoken about the power of the king but no corresponding action to demonstrate his legendary power until he was carried away by the colonizers like a baby without as much as a struggle. Hollywood, Bollywood and even Chinese movie producers will never present their historical figures or their history as inferior to another.

Despite the influence of modern forces on Africa, there are still elements of continuity and they need to show that in Nollywood movies. The traditional methods of conflict resolution that kept the African societies relatively stable and violence-free should be showcased and they should not be downplayed in favour of foreign techniques that have not worked in Africa. The fact is that the traditional methods worked for Africa and that should be emphasized in Nollywood productions with modifications where necessary to reflect modern realities.

It is important to be conscious not to replace all African traditions with European norms but to refine those that need to be refined and create a worthy civilization among the people. Some practices like polygamy, bridewealth, and burial ceremonies just to name a few are some of the practices to be reviewed or discarded for progress to be made in the society.

A work of art must reflect society, entertain and educate the people. (Alagoa \& Derefaka, 2002). 
The influences of creative arts on the development of the country are enormous. First is the preservation of the people's identity through education and production processes. The objects used by the people for domestic occupational and commercial purposes are instruments for the preservation of ethnic identity, cultural heritage and social values (Alagoa \& Derefaka, 2002). Nollywood should be the African expression of their desires, needs and expectations, and an attempt at preserving their ancestral heritage through various films of their rich cultural heritage.

The numerous roles religious leaders played in traditional African society should be shown. The collaboration between leaders and communities in times of crisis, dispute, wars and calamities to broker peace should not be overlooked, in fact, it should be celebrated because it ensured peaceful development. African religious leaders include the sacred kings and chiefs who often served as both spiritual and community leaders. Some rulers were described as gods or as endowed with God's divinity. Some of them include Benin and Oyo kings and they were revered and respected far and wide.

Even with the advent of literacy and the impact of Islam and Christianity in Africa, the king continues to function as a sacred canopy under which African traditions are subsumed and celebrated. Surely, Nollywood does not lack quality African content for its production. The integrity and progress of African society should not be sacrificed at the altar of wealth and fame.

At the other extreme of bastardizing and demonizing the African culture are the Nollywood films which make a mockery of the marriage institution. Such movies encourage abusive, toxic and unhealthy marriages. They preach that the only purpose of the girl-child is to "find" a husband and serve him for the rest of her life tolerating all his excesses and deliberate wickedness. In this context, the definition of a "wife material" is any woman who can endure and tolerate a man's wickedness without complaining or quitting the marriage. Such a woman is called a "Virtuous Woman." So the girlchild is raised to endure insults and serve all men around her humbly to show herself as wife material and be found worthy of marriage or be recommended for marriage by those who used and abused her and got no reaction from her. On the other hand, the male child is encouraged through these movies that his duty is to be irresponsible all through his growing up years, and when he is due for marriage, he gets a "Good Wife Material" as described above so that he can continue in his wicked ways with impunity. This is seen as a norm and is passed on from generation to generation. The wife spends all her years in marriage praying, fasting and crying while the husband looks for more creative ways to make her life miserable. The society permits the man to be as irresponsible as possible without consequences and his wife must accept such irresponsible behaviour as normal, she has no choice in their opinion. This scenario is glorified by Nollywood movies and is another onesided account of African society. The idea portrayed here is that of a master-servant relationship in the name of marriage.

When the girl-child is raised with the right morals to marry a boy who was trained or raised to be immoral and irresponsible, the outcome is the unhealthy, toxic and abusive relationships and marriages that are seen in Nigeria today. These films normalize and even celebrate suffering in marriage for the wife and this is a dangerous trend since Nollywood has a lot of influence on Nigerians.

Recently there has been an outcry for parents to train their male children just as they train the girls to have more healthy relationships. Of course, this outcry only came as a result of the spate of divorces in Nigeria in recent times which was hitherto unheard of.

The master-servant relationship in most Nigerian marriages is no longer good enough for most wives; hence the many recorded cases of divorces in recent times. Nollywood can do a lot by balancing this narrative to ensure healthy relationships and marriages and by extension a healthy society fit for development. After all, Nollywood is the mirror of society and as such it has to present a positive and progressive reflection of the society. 
East African Journal of Interdisciplinary Studies, Volume 2, Issue 1, 2020

Article DOI: https://doi.org/10.37284/eajis.2.1.177

\section{RECOMMENDATIONS}

Government, policymakers and all stakeholders should as a matter of urgency intervene in the affairs of Nollywood and Religion in Nigeria and intentionally position them for development because they have the capacity to birth development for Nigeria. Nollywood and Religion if properly utilized could very well provide the much-needed diversification of the Nigerian economy away from oil. Government and leadership at all levels have to stop playing the blame game and proffer home-grown solutions to the problems of the nation. Human resource is a viable source of development. Nigeria has a huge population and Nollywood and Religion also have very huge followership and viewership and the impact of these two sectors on the Nigerian people and society should not be overlooked. They need to provide them with direction and support geared towards development. Nollywood and religious leaders have a great influence on the huge population of Nigeria and indeed Africa which can be channelled to produce sustainable growth. This should be taken seriously by the government and all stakeholders.

\section{CONCLUSION}

Nollywood and religious leaders need to understand that their actions and inactions resonate with their followers negatively or positively. Therefore, there is a need for a conscious effort to send the right message to their followers and viewers bearing in mind their influence on the people and the effect on society. The Nigerian society should be able to identify things that will propel their spirit in the right direction through Nollywood and Religion. They should regulate whatever provokes the emotions of the people negatively. Subconsciously, not just the children but even the adults pick up these negative, one-sided stereotypes because the mind is a powerful tool. It is true that ultimately people make their own choices, but it is imperative to send out the right message regardless. Whether the Europeans, Nollywood or Religion is responsible for our problems or not, it is time to choose to do the right thing and take responsibility for our actions.

When there is peace and progress in society, we will all be better for it. Worship centres should be sacred and not turned into a den of robbers and followers of these religions should understand that faith without works is fruitless. Nollywood movies and religious practices should be based on verifiable facts. Indeed, everything is lawful but not everything is expedient, so there is no excuse for doing the wrong things. Nollywood and Religion should have a tremendous impact on the Nigerian society, and it should be positive. 


\section{REFERENCES}

Adebayo, D. (2012). The Paradox of High Growth and High Poverty in Nigeria. Retrieved from Spines Blog Spot, available at https://thespinesblogspot.com/2012/paradoxof-high-growth-high-poverty.

Alagoa, E. J., \& Derefaka, A. A. (2002). The Land and People of Rivers State: Eastern Niger Delta. Onyoma Research Research Publications.

Bame, K. N. (1991). Profiles in African traditional popular culture: Consensus and conflict: dance, drama, festival [s], and funerals. ClearType Press.

Belz, M. (2012, Feb 29). Targeted Christians. Retrieved from World Magazine, available at https://world.wng.org/2012/02/targeted_christi ans.

Cook, D. (2012). Boko Haram Escalates Attacks on Christians in Northern Nigeria. CTC Sentinel, 5(4).

Falola, T. (1998). Violence in Nigeria: The crisis of religious politics and secular ideologies. Rochester: University of Rochester Press.

Haruna, A. (2019, Jul 29). How Boko Haram killed 60 during funeral procession in Borno. Retrieved from Premium Times, available https://www.premiumtimesng.com/news/headl ines/343611-how-boko-haram-killed-60during-funeral-procession-in-borno.html.

Haynes, J. (1995). Nigerian cinema: structural adjustments. Research in African Literatures, 26(3), 97-119.

Haynes, J., \& Okome, O. (1998). Evolving popular media: Nigerian video films. Research in African literatures, 29(3), 106-128.

Husseini, S. H. \& Sunday, O. A. (2019). From Nigeria Film Industry to Nollywood: LandMarking the Growth of the New Wave Cinema. In Musa, B. A. (Eds), Nollywood in Glocal Perspective (p. 25-43). Palgrave Macmillan.
Kyeyune, S. (2012). Shaping the Society Christianity and Culture: Special Reference to African Culture of Baganda (Volume 2). Bloomington, IN: Author House

Mangut, J. \& Wuam, T. (eds.) (2012). Colonialism and the Transition to Modernity in Africa. Ibadan: Sam-Adex Printers.

Mbiti, J. S. (1969). African Religions and Philosophy. London: Heinemann.

Moudio, R. (2013, May). Nigeria's film industry: a potential gold mine? Retrieved from African Renewal Magazine, available from https://www.un.org/africarenewal/magazine/m ay-2013/nigeria's-film-industry-potentialgold-mine.

Odion, F. O. (2018). The Paradox of Nollywood: The Structural Intricacies and Cultural Significance of the World's Fastest-Growing Film Industry. Flinders University.

Oh, E. (2014, Oct). Nigeria's Film Industry: Nollywood Looks to Expand Globally. United States International Trade Commission (USITC). Available at https://www.usitc.gov/publications/332/erick_ oh_nigerias_film_industry.pdf.

Ojoajogwu, O. N. (2014). Religion as a catalyst of nation-building in Nigeria. Net Journal of Social Sciences, 2 (2), 71-76.

Olarinwoye, A.W. (2013). The images of women in Yoruba folktales. International Journal of Humanities and Social Sciences, 3(4), 138-149.

Olupona, J, K, (2014). African Religions: A Very Short Introduction. Oxford University Press.

Omanufeme, S. (2016). Runaway Success: Nigeria's film industry is taking off. Finance and Development, 53 (2), 31-32.

Onwuka, A. (2017, Oct 31). Nollywood is demonizing the Nigerian culture. Retrieved from Punch Nigeria, available at https://punchng.com/nollywood-isdemonising-the-nigerian-culture/. 
PwC. (2017, Jul). Spotlight: The Nigerian Film Industry. Retrieved from $\mathrm{PwC}$, available at https://www.pwc.com/ng/en/assets/pdf/spoligh t-the-nigerian-film-industry.pdf.

Quadri, Y. A. (2016). Religion in contemporary Nigeria. London: Adonis and Abbey Publishers.

Rodney, W. (1983). How Europe underdeveloped Africa and Neocolonialism: The Last Stage of Imperialism. London: Bogle-L'Ouverture Publications.

Sahara Reporters. (2014, Jun, 24). Nollywood Adds Two Million Jobs to Nigerian Economy In 20 Years. Retrieved from Sahara, available from http://saharareporters.com/2014/06/24/nollyw ood-adds-two-million-jobs-nigerian-economy20-years.

Schnell, B. (2017). Stop comparing Nollywood to Hollywood: reorienting western understanding of Nigerian cinema. Eugene, OR: University of Oregon.

Shaka, F. O. (2003). Hinigeria's emergent video film industry. Black Renaissance/Renaissance Noire, 5(2), 51-66.

Shorter, A. (1973). African Culture and the Christian Church. London: Geoffrey Chapman.

Tamuno, T. N. (1991). Peace and Violence in Nigeria. Lagos: Federal Government Press.

Ugiomoh, F. A. O. et al. (eds.) (2017). Religion and the Bounds of Culture. Port Harcourt: Rock Publishers.

Uya, O. E. (2005). African Diaspora and the Black Experience in New World Slavery. Calabar: Clear Lines Publications. 